\title{
INTERES SPÓŁKI KAPITAŁOWEJ PRZEZ PRYZMAT INTERESU WSPÓLNIKÓW (AKCJONARIUSZY)
}

\author{
THE INTEREST OF THE CAPITAL COMPANY THROUGH THE PRISM \\ OF THE INTEREST OF SHAREHOLDERS
}

\begin{abstract}
Streszczenie: W niniejszym artykule poddano szczegółowej analizie normę art. 249. § 1. oraz art. 422. § 1. kodeksu spółek handlowych w zakresie możliwości zaskarżania uchwał wspólników (akcjonariuszy), które są godzące w interes spółki kapitałowej. Przedstawiono dwie główne koncepcje pojmowania interesu spółki. Przedstawiono także koncepcje kompromisowe, które zapatrują się na pojęcie interesu spółki przez pryzmat interesu wspólników (akcjonariuszy), traktują to pojęcie jako wskazówkę do rozstrzygania kolizji interesów oraz zbliżają do ujęcia w sposób abstrakcyjny złotego środka pomiędzy swobodnym, autonomicznym podejmowaniem decyzji przez wspólników (akcjonariuszy) a zabezpieczeniem spółki przed jej dewastacją.
\end{abstract}

Słowa kluczowe: interes spółki, kolizja interesów

Received: 08.2018

\begin{abstract}
In this article, detailed analyzed the legal norm of art. 249. § 1 and art. 422. § 1 of The Code of Commercial Companies with regard to the possibility of appealing against resolutions of shareholders, that are breachting the interest of the capital company. It is presented two main concepts of the interest of company. Also it is presented compromise concepts, which look at the interest of company through the prism of the interest of shareholders and treat this idea as an indication for the resolution of the conflict of interest and allow in a abstract way to find a middle ground between free, autonomous decision-making by shareholders and securing the company against its devastation.
\end{abstract}

Key words: interest of company, conflict of interest.

Accepted: 09.2018

\footnotetext{
* Europejska Wyższa Szkoła Prawa i Administracji w Warszawie
} 
Zgodnie z art. 12. ksh, spółki kapitałowe zostały wyposażone w osobowość prawną. Spółki kapitałowe są więc osobną konstrukcją, oddzielną od wspólników (akcjonariuszy) [Sachanbińska, 2011, 117]. Oddzielność spółki od wspólników (akcjonariuszy) opiera się na dwóch podstawach: oddzielności majątkowej polegającej na braku odpowiedzialności wspólników (akcjonariuszy) za zobowiązania spółki (art. 151. § 4. oraz art. 301. § 5. ksh) oraz oddzielności organizacyjnej polegającej na zarządzaniu spółką przez powołane organy [Szumański, 2000, 20-21]. Jednakże opisane oddzielności nie powodują całkowitego odseparowania wspólników (akcjonariuszy) od spółki i jej organów. Spółka kapitałowa i jej organy powinna tworzyć ze wspólnikami (akcjonariuszami) funkcjonalny związek. Jednakże, jak pokazuje praktyka, w miarę realizowania coraz większych przedsięwzięć, wizja sposobu działania spółki i osiągania celów, zaczyna być coraz bardziej rozbieżna pomiędzy poszczególnymi wspólnikami (akcjonariuszami) [Oplustil, 2010, 17] a także zarządem, co często powoduje niepożądane (a nawet dewastacyjne) dla spółki działania tych pierwszych. Dla ochrony spółki przed takimi działaniami wspólników (akcjonariuszy) ustawodawca przewidział odpowiednie narzędzia prawne, z których do najważniejszych powinno się zaliczyć, wyrażoną w art. 249. § 1. oraz w art. 422. §1. ksh, możliwość zaskarżania uchwał wspólników (akcjonariuszy), które są godzące w interes spółki. W tym miejscu należy jednak zadać pytanie, jakie działania wspólników (akcjonariuszy) podpadają pod normę rzeczonych przepisów? Do odpowiedzi na to pytanie konieczne jest przeprowadzenie analizy pojęcia interesu spółki.

Kodeks spółek handlowych nie posiada definicji legalnej interesu spółki, wobec czego powstała wokół tego pojęcia dyskusja, z której wyłoniły się dwie główne koncepcje.

Na początku należy wspomnieć R. Longchampsa de Barier, który interesem nazwał stosunek pewnej istoty do świata zewnętrznego, polegający na tym, że ta istota, ze względu na cel, do którego dąży, czegoś potrzebuje a ta potrzeba może być w zasadzie zaspokojona. R. Longchamps de Barier podkreśla, że nie jest konieczne do pojęcia interesu, aby interesowany sam go odczuwał i jego zaspokojenia sobie życzył [Longchamps de Berier, 1911, 97]. Na tym gruncie wyrosła pierwsza koncepcja wyrażana m.in. przez A. Radwana, że interes spółki powinien, z uwagi na posiadanie przez spółkę przymiotu 
osobowości prawnej, być przynajmniej dogmatycznie oddzielony od interesu akcjonariuszy. Żadne z tych pojęć nie może również być rozumiane jako pojęciowo nadrzędne w stosunku do drugiego [Radwan, 2004, 293]. Podobnie wypowiadają się M. Allehandr [1992, 435] i S. Sołtysiński [1996, 435]: ponieważ pomiędzy partykularnymi interesami poszczególnych grup akcjonariuszy zachodzą nieraz spore różnice, interes spółki nie może być utożsamiany z interesem którejkolwiek z tych grup, nawet jeżeli chodzi o akcjonariusza większościowego [Radwan, 2004, 293].

Z drugiej strony należy wspomnieć także F. Zolla, który twierdził, że do zaistnienia osoby prawnej potrzeba przede wszystkim pewnego materialnego substratu, z którym by łączyć można, według ustaw obowiązujących, prawną osobowość. Po wtóre potrzeba, aby ten substrat powstał dla pewnego społecznego celu, który nie jest tylko celem pewnej jednostki lub prawnych jednostek, ale przyświeca szeregowi bliżej nieoznaczonych, mniej lub więcej dowolnie zmieniających się ludzi [Zoll, 1946, 119]. Na tym gruncie z kolei wyrosła druga koncepcja, wyrażana m.in. przez A. Opalskiego, który zauważył, że spółka ma „własny” interes gospodarczy, „własną” politykę i „własną” strategię rozwoju tylko wtedy, gdy postrzega się ją z perspektywy osób trzecich. W rzeczywistości interes spółki determinują osoby uprawnione do podejmowania korporacyjnych decyzji: akcjonariusze i funkcjonariusze. W pewnym stopniu interes ten współtworzą też podmioty z otoczenia spółki (przede wszystkim pracownicy, wierzyciele, społeczności lokalne), których działania, pozostające z reguły poza sferą mechanizmów korporacyjnych, mogą istotnie wpływać na zachowania spółki i w ten sposób przyczyniać się do kształtowania jej interesu. Interesu spółki nie da się ustalić w sposób abstrakcyjny i obiektywny. Stanowi on raczej wypadkową ścierających się subiektywnych przekonań poszczególnych grup korporacyjnych decydentów [Opalski, 2006, 151]. W podobnym tonie wypowiada się K. Oplustil, że autonomiczny charakter spółki jako osoby prawnej nie może prowadzić do uznania, że również interes spółki należy definiować w zupełnym oderwaniu od interesów tych podmiotów. Spółka kapitałowa, będąca sztuczną, prawną konstrukcją, nie istnieje przecież „sama dla siebie”, lecz ekonomicznym sensem i celem jej bytu prawnego jest przede wszystkim realizacja interesów gospodarczych jej założycieli i akcjonariuszy, stanowiących osobowy substrat 
spółki [Oplustil, 2010, 173]. Także D. Wajda twierdzi, że członkowie zarządu i organu nadzorczego powinni działać w interesie spółki, którego jednak podstawowym elementem jest dbanie o interes akcjonariuszy (wspólników) [Wajda, 2009, 26].

Przechodząc do analizy problemu, wydaje się, że pogląd o autonomiczności interesu spółki jest trudny do obronienia.

Po pierwsze, taki pogląd stoi w opozycji do występujących relacji pomiędzy interesem spółki i celem spółki. Przyjąć należy, że zgodne z interesem spółki jest to, co służy realizacji jej celu (art. 3. ksh), a tym co charakteryzuje cel spółki jest istnienie jego wspólności wśród wspólników [Wajda, 2009, 21]. Należy przyjąć, że wspólny cel wspólników czy akcjonariuszy leży u podstaw utworzenia spółki, co oznacza, że to właśnie wspólnicy czy akcjonariusze konstruują cel spółki [Wajda, 2009, 23]. W podobnym tonie wypowiada się K. Oplustil, który zauważa, że wspólnym celem realizowanym przez wspólników (akcjonariuszy) w ramach spółki akcyjnej jest z reguły maksymalizacja jej wartości oraz osiąganie przez nią zysku, który następnie może zostać wypłacony akcjonariuszom w postaci dywidendy. Interes spółki stanowi więc pewną wypadkową (funkcję) interesu osób, które przyczyniają się do sukcesu gospodarczego spółki i mogą być jego beneficjentami [Oplustil, 2010, 173-175].

Ponadto tylko od strony prawnej to spółka jest właścicielem swojego majątku, od strony ekonomicznej natomiast jego właścicielami są akcjonariusze [Szumański, 2006, 738]. Ponieważ akcjonariusze są „właścicielami” spółki dzięki posiadanym przez siebie udziałom w kapitale zakładowym oraz ponoszą finansowe ryzyko niepowodzeń spółki, to właśnie ich interesom należy przyznać pierwszeństwo [Sachanbińska, 2011, 138-139].

Uzasadnieniem dla tej koncepcji mają być także unormowania kodeksu spółek handlowych, które przyznają wspólnikom (akcjonariuszom) najszersze spektrum uprawnień [Opalski, 2008, 18]. Nawet w spółce akcyjnej, którą cechuje najdalej idąca instytucjonalizacja, wyznacznikiem interesu spółki jest interes akcjonariuszy. Wprawdzie walne zgromadzenie nie ma prawa wydawania zarządowi wiążących poleceń, ale statut może rozszerzyć obowiązek uzyskania przez zarząd zgody walnego zgromadzenia [Gębusia, 2017, 34].

Podnosi się również, że menedżerowie powinni ponosić odpowiedzialność za swoje działania wobec wyraźnie określonego podmiotu, w przeciwnym wy- 
padku mogliby uzasadniać dobrem spółki niemal wszelkie działania, z wyjątkiem przypadków oczywistej niegospodarności [Opalski, 2008, 18].

Z drugiej strony kodeks spółek handlowych wyraźnie stanowi o możliwości uchylania uchwał w przypadku godzenia w interes spółki, a więc ustawodawca uznał, że w niektórych sytuacjach interes spółki nawet spolaryzowany interesem wspólników (akcjonariuszy) jest ważniejszy od interesu samych wspólników (akcjonariuszy).

Z tego powodu w ostatnim czasie pojawiają się koncepcje kompromisowe, które zyskują coraz szersze uznanie.

Sąd Najwyższy w wyroku z 5 listopada 2009 r., sygn. akt I CSK 158/09 wyraził następującą tezę: interes spółki handlowej odpowiada interesowi wszystkich grup jej wspólników z uwzględnieniem wspólnego celu określonego w umowie (statucie) spółki. W uzasadnieniu stwierdzono, że interes spółki handlowej jest wypadkową interesów wszystkich grup jej wspólników określaną z uwzględnieniem zastrzeżonego w umowie lub w statucie spółki wspólnego celu, do osiągnięcia którego wspólnicy zobowiązali się dążyć. Ten niezbędny element umowy (statutu) każdej spółki handlowej, określony w art. 3. ksh, decyduje o tym, że nie może istnieć odrębny, samodzielny interes spółki jako osoby prawnej, abstrahujący od wypadkowej interesu wszystkich wspólników, determinowanej określonym w umowie spółki wspólnym celem. Pojęcie „interes spółki” jest więc ustawową ogólną formułą, której wypełnienie wymaga uwzględnienia kompromisowo rozumianej funkcji przekonań, dążeń i zachowań wszystkich grup wspólników, określonej z uwzględnieniem wspólnego celu. Interes spółki wyznaczają więc wszystkie te dążenia i zachowania wspólników, które zmierzają do osiągnięcia wspólnego celu przyświecającego jej zawiązaniu i określonego w umowie lub statucie spółki, w którym cel ten jest jego konstytutywnym elementem.

D. Wajda proponuje traktowanie spółki jako szczególnej struktury organizacyjno - prawnej przedsiębiorcy, co oznacza, że stanowi ona wspólnotę celów, co powoduje, przy rozważaniu interesów spółki przez pryzmat wspólników, zachowanie obowiązku lojalności po stronie wspólników [Wajda, 2009, 20].

A. Radwan zauważył, że w spółce ogniskują się rozbieżne interesy bardzo wielu grup, nie tylko samych wspólników, wobec czego proponuje po- 
strzeganie interesu spółki jako rozstrzygnięcie tego konfliktu zgodnie z zasadami słuszności [Radwan, 2004, 293]. O. Sachanbińska wyraziła pochwałę tej koncepcji z tego powodu, że co do zasady odwołuje się ona do interesów uczestników spółki, nie wynika z niej natomiast jednoznacznie, do jakiego stopnia należy uwzględniać także interes innych grup poza wspólnikami oraz czy interesy wszystkich grup są sobie równe [Sachanbińska, 2011, 121].

Jeszcze lepszym kompromisem wydaje się postrzeganie interesu spółki jako rozstrzygnięcie występujących konfliktów interesów w spółce, ale zgodnie z ekonomiczną zasadą racjonalnego gospodarowania. Skoro interes spółki winien uwzględniać przede wszystkim interes wspólników (akcjonariuszy), to uchwały wspólników (akcjonariuszy) z powodu godzenia w interes spółki, powinny być uchylane tylko w wyjątkowych sytuacjach, kiedy taka uchwała jest dewastacyjna dla spółki, czyli jej prognozowane korzyści nie są proporcjonalne do poniesionych, w wyniku podjęcia uchwały, strat. Przy czym jak już zauważono, zarówno straty jak i korzyści mogą być ekonomiczne (majątkowe) lub pozaekonomiczne (niemajątkowe, społeczne) [wyrok SN z 5 listopada 2009 r., I CSK 158/09]. Ocena, czy doszło do godzenia w interes spółki, musi być dokonana w odniesieniu do konkretnej sytuacji, w jakiej znajduje się spółka, w porównaniu do sytuacji, w jakiej znajdzie się w wyniku podjęcia danej uchwały [wyrok SO w Warszawie z 20 września 2012 r., XXVI GC 524/12]. Natomiast nie można uważać za godzenie w interes spółki działania biznesowego wspólników (akcjonariuszy), które są ryzykowne, ale istnieje określone (odpowiednie do ryzyka) prawdopodobieństwo przyniesienia spółce proporcjonalnej korzyści w przyszłości.

Podsumowując, pojęcie interesu spółki jest dość pojemne i stosunkowo nieostre, co sprawia, że zapełnienie go treścią normatywną pozostaje zadaniem doktryny i orzecznictwa [Radwan, 2004, 293]. Pojęcie interesu spółki jest więc wskazówką dla rozstrzygnięcia ewentualnej kolizji interesów, służącą przyczynianiu się wzrostowi wartości rynkowej jej walorów [Błaszczyk, 2011, 908]. Podobnie uważa I. Gębusia, która twierdzi, że interes spółki ma ze swej jurydycznej natury charakter nieostry i abstrakcyjny. Jej konkretyzację ustawodawca powierzył w przypadkach spornych organom wymiaru sprawiedliwości, które in casu powinny rozpatrzyć pojęcie interesu spółki przez pryzmat wartości prawnych oraz aksjologii pozaprawnej [Gębusia, 2017, 39]. 
Takim pryzmatem powinien być interes wspólników (akcjonariuszy), który powinien ustępować interesowi spółki tylko w przypadku próby jej dewastacji poprzez podejmowanie uchwał, których spodziewane korzyści dla spółki są niewspółmierne do poniesionym strat.

\section{Bibliografia:}

Allerhand M., Kodeks handlowy, Bielsko-Biała 1992.

Błaszczyk P., Pojęcie interesu spółki handlowej a "lekcja" kryzysu gospodarczego, Kwartalnik Prawa Prywatnego, Warszawa 2011, vol. XIX, nr 4.

Gębusia I., Interes spółki w prawie polskim i europejskim, Warszawa 2017. Longchamps de Berier R., Studya nad istotą osoby prawniczej, Lwów 1911. Opalski A., O pojęciu interesu spółki handlowej, Przegląd Prawa Handlowego $11 / 2008$.

Opalski A., Rada nadzorcza w spółce akcyjnej, Warszawa 2006.

Oplustil K., Instrumenty nadzoru korporacyjnego (Corporate governance) w spółce akcyjnej, Warszawa 2010.

Radwan A., Prawo poboru w spółce akcyjnej, Warszawa 2004.

Sachanbińska O., Internetowy Przegląd Prawniczy, TBSP UJ 2011, nr 2.

Sołtysiński S., Szajkowski A., Szwaja J., Kodeks handlowy, t. II, Warszawa 1996.

Szumański A., Hybrydalne typy spółek handlowych, PPH 6/2000.

Szumański A. Pyzioł W., Weiss I., Prawo spółek, Kraków-Bydgoszcz 2006.

Wajda D., Obowiązek lojalności w spółkach handlowych, Warszawa 2009.

Wyrok Sądu Najwyższego z 5 listopada 2009 r., sygn. akt I CSK 158/09.

Wyrok Sądu Okręgowego w Warszawie z 20 września 2012 r., sygn. akt XXVI GC 524/12.

Zoll F., Prawo cywilne w zarysie. Część ogólna, t. 1, Kraków 1946. 